\title{
I3
}

\section{The Bridge: A Drama}

\author{
Cast of Characters
}

DEPUTY ARCANGELI: chief deputy, Seneca County Sheriff's Department SHERIFF'S DEPUTIES

POLICE CHIEF: Doyle Marquardt, of the Waterloo police

WATERLOO POLICEMEN AND FIREMEN

SHERIFF: Ken Greer, elected sheriff of Seneca County

KIM: an encampment mediator, native of Geneva, New York, six feet, six inches tall

REPORTER: male reporter for local radio station, carrying tape recorder MELLEY KLEMAN: fifty-six-year-old Waterloo resident

MAZIE KLEMAN: her daughter

TOM KLEMAN: Melley's husband, local bank president

YOUNG MAN: friend of the Klemans'

LONNY: Vietnam veteran, thirty-five to forty years old

WOMAN WITH LONNY: his wife

MATRONS: employees of sheriff's department

ARRESTED WOMEN FROM PEACE CAMP

MEN, WOMEN, AND CHILDREN IN CROWD

WOMEN PROTESTERS FROM PEACE ENCAMPMENT

PEACEFUL MAN: encampment sympathizer

JAY COOPER: man with rifle

Scene $I$

A crowd has gathered on the bridge over the barge canal in the town of Waterloo, New York. It is midday, sunny and hot. Crowd rumblings rise and fall. Occasionally group chants and individuals shouting can be discerned. The crowd has been on the bridge over an bour, blocking a march by a group of women antinuclear protesters. 
The crowd consists of about three hundred to four hundred people of both sexes and all ages including many teenagers; people are dressed in summer clothes: tank tops, T-shirts, shorts. Some women are in hair curlers; many men are bare chested. At least half the crowd is holding or waving small American flags; some people are holding large American flags; one person waves a large black and white POW/MIA flag. A group of men thirty-five to forty-five years old are holding a banner across the bridge that reads: "Many men and women have earned the right for anyone to protest in America. Respect them, our flag, and our country." Others hold hand-lettered cardboard signs that say, "You Can't Overrule God," "Go Home," "We're Proud to Be Americans," "Dyke Farm That Way," "If You Love America, Protect It," and "Pinko Lesbians, Go Home!"

Sitting in a circle in front of the crowd is a group of about thirty women of different ages. Most are wearing white bibs with the names of historically important women written on them; they talk to each other and to other women standing around them. Some are crying, some look frightened, some seem passive. Occasionally they sing protest or peace songs. When they attempt patriotic songs the crowd takes over and drowns them out.

The crowd is chanting, "Go home! Go home!" and people are jabbing their flags into the air above the seated women. Several sheriff's department cars pull up in the background.

MAN I (screaming): Come on lesbians, lick communism, not each other! (Laughter by several people around him).

WOMAN r: Right!

MAN 2: That was a good one.

WOMAN 2: Arrest them.

YOUNG WOMAN I (screaming): Hey you bunch of commies.

CROWD (several times): Get out of here. Go home.

YOUNG WOMAN I (screaming): Hey you fucking commies.

CROWD (repeatedly): A-mer-i-ca! A-mer-i-ca!

MAN 3: Go back to Russia!

Sheriff's deputy Dale Arcangeli gets out of a car and walks up to the police chief, who is standing calmly at the edge of the crowd talking to some men. DEPUTY ARCANGELI (to police chief): Hey, Doyle, What's going on? POLICE CHIEF (to man 4 in crowd as Deputy Arcangeli listens): So you're going to stop them here on the bridge just for a little while? 


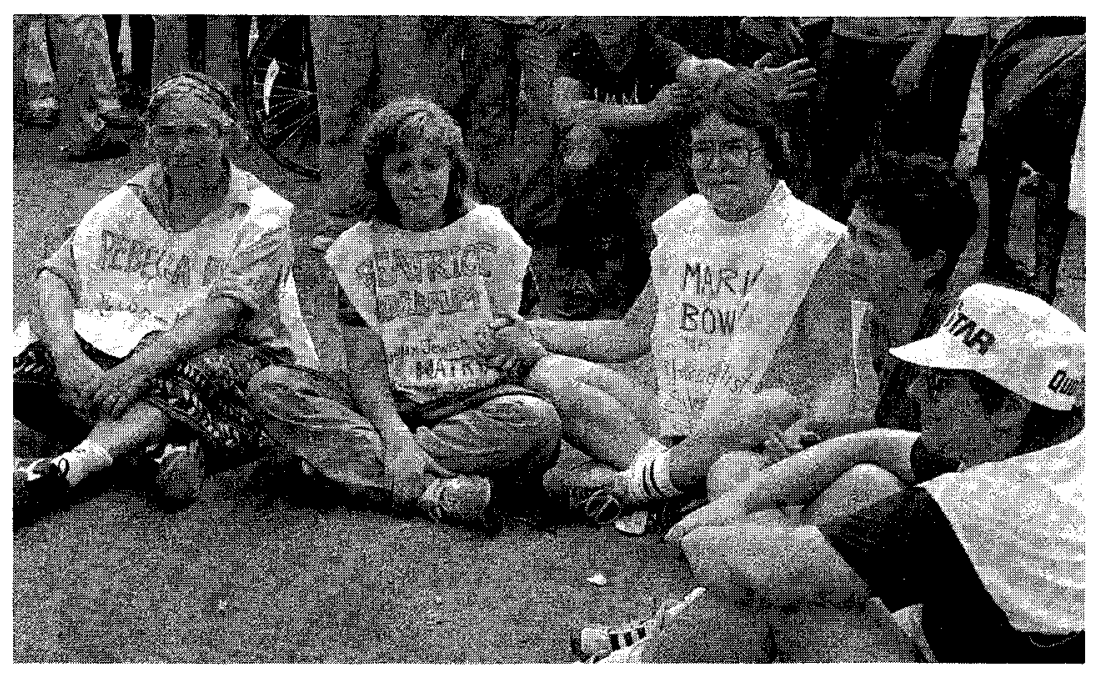

Encampment women in circle on Waterloo bridge. Photo by Pam Quiggle

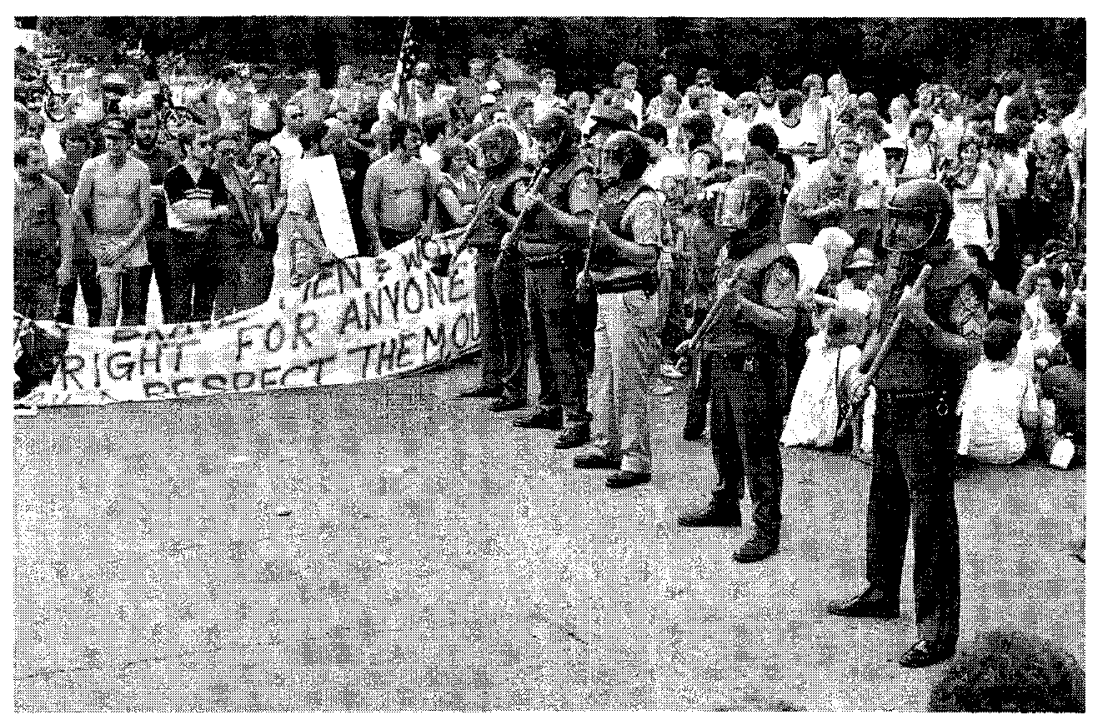

Protesters, sheriff's deputies, and residents face off at bridge in Waterloo. Photo by Pam Quiggle 
MAN 4: We're going to hold them for a little while and then let them go. POLICE CHIEF: Nobody's going to get physical, right?

MAN 5: Nobody's going to get physical, nothing.

Woman protester I approaches crowd and tries to talk to them. Her words cannot be heard over the chant "Go home!"

MAN I (addressing woman protester I but turning away at an angle): Get out of here; we don't want to hear it. Listen, we're decent people, not lowlife like you.

WOMAN PROTESTER I (sarcastically): Thank you for allowing me my freedom to....

MAN 2: Up yours. Get out of here. We're decent people; we don't have trash. We got enough trash in this town.

CROWD: Go home!

Buddhist drum begins beating in background.

MAN 6: Now's the time to move in, stomp the piss out of them, and throw them in the canal.

WOMAN 3: You all need psychiatrists.

Other women protesters are mingling with the crowd, having both calm and angry exchanges with them.

WOMAN PROTESTER 2 (To man Io in crowd): . . . so we want nuclear weapons stopped.

MAN IO: You can't just get rid of the weapons. With the situation the way it is we'd all be dead. You have to face reality.

WOMAN PROTESTER 2: The reality is that we have to change things now. MAN 2: Bullshit! You people want ERA, you join the fucking army, you go to Vietnam.

CROWD: U-S-A! U-S-A!

MAN 2 (to woman protester 2, disgusted): Oh, go home.

CROWD: Go home! Go home!

WOMAN PROTESTER 3 (to people in crowd): If you'd like to talk to us, we'd like to listen to you.

MAN IO: Ma'am, that's not going to accomplish anything at this point. WOMAN PROTESTER 3: Okay, but....

MAN IO: It's not going to accomplish anything at this point.

MAN 4: Communists! Go protest in Russia. That's where you belong.

WOMAN PROTESTER 4 (To man I and woman 5): The situation we're in now, it's like a bathtub filled with gasoline with two people standing in it 


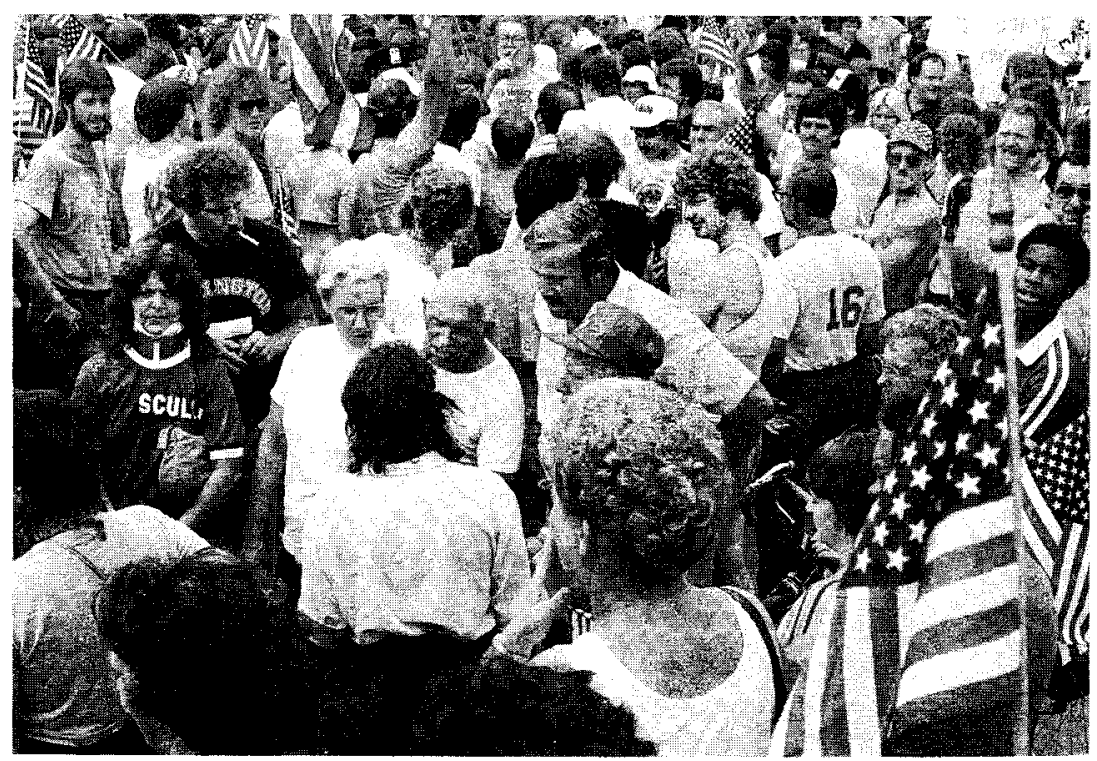

Encampment women and residents on the bridge in Waterloo. Photo by Pam Quiggle

and one has 780 matches and one has 762 . It doesn't matter how many matches you have, the first match will do it.

WOMAN 5 (laughing): Well if there are two men standing in a bathtub, I hope the American is the first to light the match!

MAN I: Get out of here. We don't listen to commie lesbians.

Crowd tries to poke protesters with the ends of their flag poles.

POLICEMAN I: Hey, come on. Keep it up straight, keep it up in the air, Bobby.

A man named Lonny is in the front line of the crowd. Somewhat intoxicated, red in the face, and agitated, Lonny continuously screams and gestures at the women.

POLICEMAN 2: Come on, Lonny, don't get hot.

WOMAN WITH LONNY (trying to restrain Lonny): Lonny, please.

LONNY: No! I goddamn fought for my country and it's fucking time we won right.

MAN IN CROWD: Wave that flag! Wave that flag!

LONNY (shouting to policeman I): Officer, there's not no permit for this parade, right? There's no permit for this parade. 
MAN I I: We don't want you here.

WOMAN 6: Com-mies! Com-mies!

REPORTER (holding microphone up to Lonny): What are you doing here? LONNY (his voice cracks): What am I doing here? I'm a goddam Vietnam veteran, that's what I'm doing here.

REPORTER: Have you got a permit to block the bridge?

LONNY: Nobody's got a permit.

REPORTER: Then why don't you get out of the road?

MAN I 2 (to reporter): Why don't you shove that mike up your ass, pal.

MAN ${ }_{3} 3$ (To reporter): What are you, queer like them?

Policeman 2 comes up and takes Lonny's arm.

LONNY: Get your fucking hands off me please officer.

WOMAN WITH LONNY: Lonny, will you get out of here!

POLICEMAN 2: I'm going to arrest you if you don't....

Woman with Lonny tries to get him away from reporter and policeman 2. WOMAN WITH LONNY (to man Io): Will you get him out of here? (to Lonny) Lonny.... Lonny!... Lonny please!... Lon-ny!!

CROWD: U-S-A! U-S-A!

LONNY (to reporter): Give me that mike! I'll tell you what I got. I got three goddamn brass stars. I got injured twice defending my country, and defending you and this officer. (Reporter gives a mock bow.) Oh yeah, okay, a nice bow. You know what we get from the VA? Nothing! They say we're all nuts!

WOMAN WITH LONNY: Lonny, let's get out of here. Lonny, come on (pleading).

LONNY: I got home from Vietnam, I got shit (voice cracks).

WOMAN WITH LONNY: Lonny, come on.

POLICEMAN 3: That's enough, Lonny.

LONNY (Turning suddenly to reporter): I got your face pal (groaning) oh, yeah.

WOMAN WITH LONNY: Lonny, goddamn it.

LONNY (turning back toward protesters, screaming): No goddam permit. MAN II: We did our thing, man. Hey, we did our thing.

LONNY: I did my thing. You people sent me out to do it better. I'll tell you, the vet will survive. They will survive.

WOMAN 6 (to policemen): Why do we get arrested? Arrest them! 
WOMAN WITH LONNY (growling): Lonny, you're going to get arrested, just stop.

LONNY: No, goddamn, arrest nobody. It's not even a civil disturbance.

WOMAN WITH LONNY (growling): God almighty!

MAN I 2: I'll tell you I'm a disabled vet, and I protected my country to look at this shit?

POLICEMAN I (to Lonny): You have proved your point, come on.

LONNY: We have proved no point.

(Another part of crowd)

MAN I3: Hey, go home and smoke that crap.

MAN I4: Go home and get the hell out of here.

MAN I 3: Hey, we live here, we don't worry about it.

CROWD: Love it or leave it. Love it or leave it.

MAN I5: You fucking don't belong here.

WOMAN 7: You're a sick specimen of woman with your tits hanging out. MAN I6: Communists! Bunch of communists! We fought for you when you were growing up and now you're turning against us.

woman 5: Hey, my brother was killed when they bombed Pearl Harbor! MAN I 4: You're just a bunch of fucking communists that supported the goddamn people that put us in Nam.

WOMAN PROTESTER 4 : We love our country too.

WOMAN 7 (to woman protester 4): You can't change things by doing this. You think you're gonna change it? Giving my daughter literature on lesbianship, that's going to change it?

MAN I 8: Why do you get your goddamned nose involved? Cause you can't do a goddamn thing. Leave! Go back to where you're from. We don't want to hear your bullshit. Go on! Go on! Save your breath, honey!

MAN I 5 (to woman shaking rattle): Don't put no fucking hex on me, you bitch.

(Another part of crowd)

MAN I8: Go protest in Russia-that's where you belong.

MAN 19: If you were doing this in Russia, they'd lock you up, send you to Siberia.

woman 9: You can't do these kinds of things in Russia. They don't let you climb fences and stuff. So why are you doing it here?

Women protesters sitting on ground start singing "God Bless America." 
CROWD: Go home, commies! (repeatedly).

CROWD: Go home, lezzies! Nuke the lezzie Jews!

VOICE ON POLICE RADIO: Dispatcher says they have a full scale riot at the bridge.

(Another part of crowd)

WATERLOO POLICEMAN I: Sheriff just told me he wants them all to march up back to the village square and have people from the encampment come out and pick them up and truck them down. He doesn't want them walking through Waterloo anymore.

DEPUTY I: Yeah, but those guys won't let them through, and I'm not sure what will happen if more encampment women show up.

The sheriff is talking to a group of the women protesters.

SHERIFF (impatient): Lady, you are asking for trouble here.

WOMAN PROTESTER I (to sheriff): We're not doing anything.

WOMAN PROTESTER 5: They're the ones who are asking for trouble. We're not....

WOMAN PROTESTER 6: They're the ones who are blocking the road.

WOMAN PROTESTER 4: We're just walking.

SHERIFF: Do as I tell you. You are the people that came into this town. WOMAN PROTESTER 3: That's true.

SHERIFF: You are the outsiders. Now get it up and come on. Come down here and gather in the parking lot.

(Women complain all together that they have a right to cross the bridge.) SHERIFF: I can't listen to four yacking ladies in my ears at the same time. WOMAN PROTESTER 5 : I don't know why you are not considering that they are inciting a riot.

SHERIFF: Move it out ladies.

WOMAN PROTESTER I: Why?

SHERIFF: You are invaders in this village.

WOMAN PROTESTER I: We're not invaders; we belong to the same country. SHERIFF: You know, I've got total uncooperation from you people. Now you were advised when you went to that encampment that they didn't want problems with the sheriff's department. And now they are sitting here irritating the situation to no end.

WOMAN PROTESTER 2: We have a right to walk on a public highway SHERIFF: I, goddamn it, I know you do. I'm asking you to move it. 
WOMAN PROTESTER 4: That's your job to have us keep the law. SHERIFF: It's my job and I'm going to have to arrest every one of you if you stay here.

WOMAN PROTESTER 6 (calmly and sarcastically): I guess you might have to. SHERIFF: Well I just might do that (sarcastically). WOMAN PROTESTER 6: You might have to. SHERIFF: What are you, the spokesman for this group? WOMAN PROTESTER 6: No, I'm speaking for myself.

Sheriff's department paddy wagon pulls up. A deputy gets out of the front seat and opens the back door. One man in riot gear quickly jumps out. The deputy angrily tells him to get back in so they can all jump out together. Sheriff's deputies in riot gear (helmets, face shields, body padding) carrying batons, then jump out of the paddy wagon. The crowd cheers when they see them. When the deputies head toward crowd and place themselves between the crowd and the seated women, the crowd hoots and jeers. Firemen with walkie-talkies and WFD (Waterloo Fire Department) baseball caps begin to infiltrate the crowd.

MAN 7 (nodding toward the line of sheriff's deputies): Where the hell do they think they're going.

wOMAN 3: They look like Martians coming in for a landing.

MAN 8: This is ridiculous. Just get those stupid women out of here.

TEENAGERS IN CROWD: Get out of here, you jerks, you assholes.

MAN 9: Take the long way.

CROWD: Go home! (ten times)

The sheriff walks away disgusted from the women and starts giving directions to deputies in riot gear.

SHERIFF: Start loading them up. We're going to start loading them in the patrol car and arrest them (crowd cheers). Have these officers swing over the ambulance and we're going to start loading them up, and I'll see to it that every damn one of them goes a month before they're arraigned. (Turns back to the group of women he was talking with.) You go to jail if you don't move it.

PEACEFUL MAN (comes up to sheriff and interrupts): The reason they are sitting there, sir, is because they're not being let through.

SHERIFF: I've got a riot on my hands and I don't need your advice. (Turns to a deputy; points at peaceful man.) Get this guy's full name and address. If he causes any more problems, I want to have him arrested. 
Sheriff gets on hollow-sounding bullhorn; the crowd is suddenly silent.

SHERIFF: Attention, ladies! You were advised when you entered the antinuke encampment that they did not want problems with the local taxpayers and the county sheriff's department (one boo). You are not keeping that promise. If you remain here... (silence) inciting a riot... (another silence, interrupted as crowd begins to cheer). I am asking you.... If you do not follow the patrol car and disperse, I will be forced to arrest (cheers). You will not be issued a mild letter (louder cheers). Attention! This is Ken Greer, sheriff. I am ordering you to follow that patrol car back to the parking lot at the sheriff's department. If you follow the patrol car to the parking lot, you will be allowed to continue your march later. This message is for those women from the antinuke encampment. I am asking you for your cooperation.

Kim is talking to some of the men who blocked the bridge. Many of them come up only to her chest.

CHILD (taunting Kim): Hey, bigfoot!

MAN 20 (to Kim): Go out of here and don't bother us. We'll all make sure; we'll help these deputies and make sure nobody gets hurt. As long as they go down this road and get out of town we won't bother them. They'll be free and we'll even protect them to get out. Nobody will touch them or bother them. No one.

KIM: All right, well, what we have said, what we have agreed is that if we start going that way, you will stay here and we're going to go that way. MAN 4: The crowd will hold back, we promise.

MAN 20: We'll hold the crowd here. Just don't come back this way.

KIM: Okay, I wanted to let you know that I talked to....

WOMAN PROTESTER 5: What about our cars here?

MAN 22: You're going to have to figure out a way to get them, like we said.

WOMAN PROTESTER 6: Well we don't got helicopters.

MAN 23: When you got arrested at the depot they dropped you off at the other end-you had to get back to your cars too. Worry about thatthat's your problem - we didn't call you here. You came. You should have thought about that before you came here. This ain't Romulus. We care about our town.

KIM: My name's Kim.

MAN 20: Okay, just get them out. We want them out. 


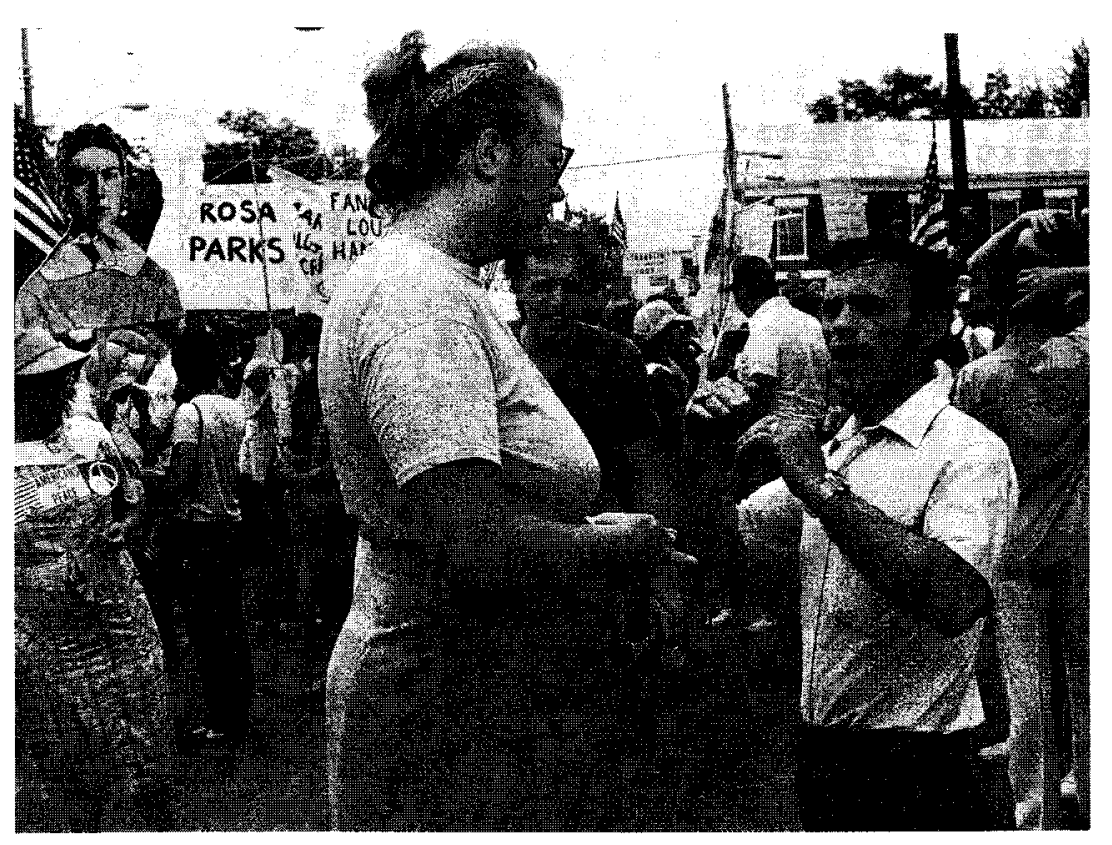

Kim Blacklock of the encampment talks to Sheriff Ken Greer in Waterloo. Photo by Pam Quigle

MAN 2I: Tell them we want them going.

MAN 22: That's all we want.

SHERIFF (to crowd, on bullhorn): Please cooperate. I'm asking the individuals or group who is on the other side to disperse, to go back to your business establishment or your home.

Tear gas is released by someone in the crowd.

PEOPLE IN CROWD: Tear gas? Tear gas? Are they bringing out tear gas? Did somebody just leak some tear gas?

REPORTER; Someone's leaking tear gas. Shit, I didn't think they had tear gas in Waterloo!

SHERIFF (on bullhorn): I'm asking the local citizens to disperse and return to your homes. Please. This is a volatile situation and I am asking for your cooperation. Those local citizens that are gathered here-any expenses resulting from this demonstration or from a riot situation will be passed down to the local taxpayers. 
REPORTER (To sheriff's Deputy): Hey, Dale, you guys using tear gas? What's that smell?

DEPUTY ARCANGELI: No, somebody threw it; it's somebody here.

SHERIFF: ...the cost will be attributed to you if you refuse to disperse. In addition, you will also take the chance of being arrested for inciting a riot. All children are also to leave. All citizens are requested to leave. Immediately. (Gives bullhorn to encampment woman.)

WOMAN FROM THE ENCAMPMENT (on bullhorn): In the spirit of free activity, in the spirit of searching for alternatives, in the spirit of teaching the community here that we love them and they are part of us and we are part of them, I urge you that we accept an alternative route, that we continue our march, that in about five minutes we turn around, we take our walk as we did before, that we follow the red car over there. The police has promised us, Sheriff Greer has promised us he will back us up. We search for alternatives to peace. Let's search for an alternative right now, in the spirit of reconciliation.

(Light applause, some boos from males; the women seated refuse to go.) SHERIFF (to same peaceful man who interrupted him before and is standing nearby): I don't know who you are, fellow, but I'm not backing down, and I just gave you an order a few minutes ago for the citizens to disperse. Now move it! folks. Move out. Go back to your homes. What are you waiting for? You are disobeying a police order. You are, by remaining, inciting a riot situation. (Crowd starts chanting "Go home" again.)Ladies from the encampment, I am asking you also to disperse. I am asking you to immediately move out.

The sheriff gives orders for the women on the ground to be put into waiting ambulances and paddy wagon. The crowd, which was beginning to disperse, comes rushing back as the deputies grab the women by their ankles and wrists and carry them away. Most of the women go limp. The crowd cheers and jeers, calling out to the deputies by name, telling them they are doing a great job. Jay Cooper, wearing a fatigue jacket and carrying a rifle on his shoulder comes walking toward the women on the ground. Several sheriff's deputies and firemen see him and wrestle him to the ground. He is taken away.

Melley Kleman and her daughter Mazie come to the front of the crowd and find themselves next to the group of seated women. About twenty-five women have already been dragged away. About nine or ten are still sitting in the circle. As one woman is removed, another encampment woman sits 


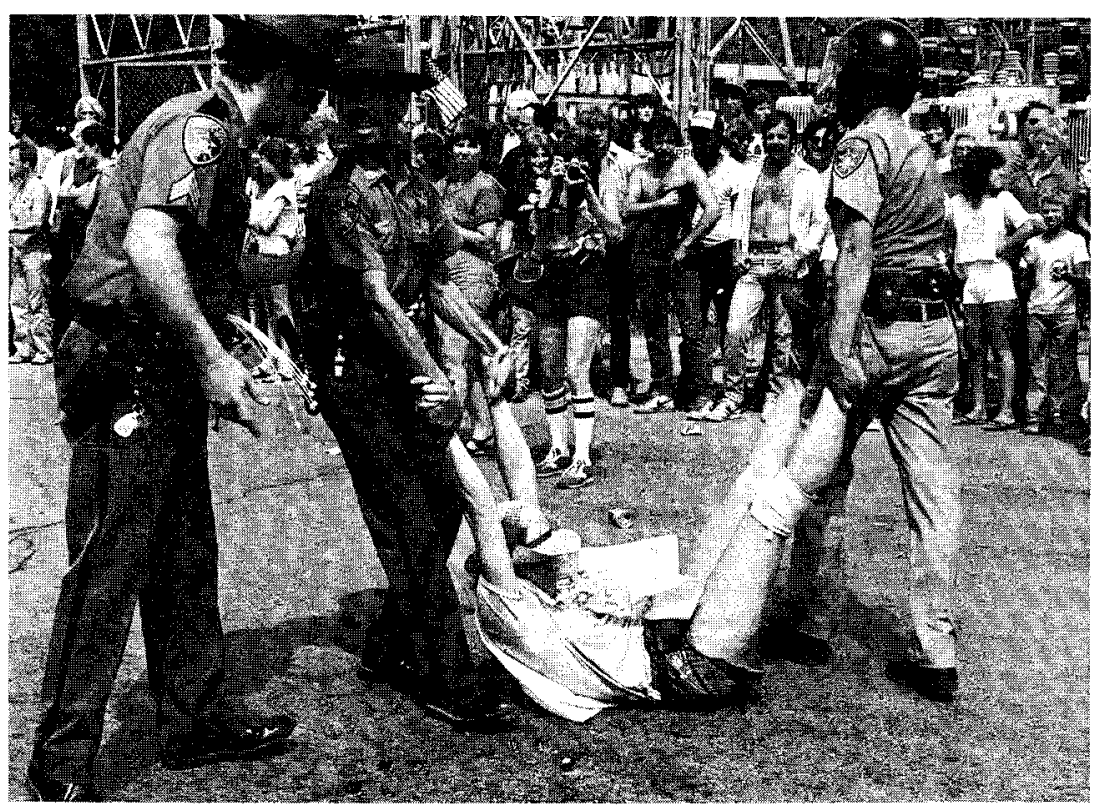

Woman being arrested in Waterloo. Photo by Pam Quiggle

down to take her place. Melley and Mazie watch; then Melley goes over to her husband Tom, who is talking to a newspaper reporter.

MELLEY (to Tom): What are they doing?

Tom: Well, the women tried to walk through and, uh, the townspeople formed a barrier and wouldn't let them through.

Melley: But what are they doing? Who are they arresting?

TOM: They're arresting them, the women.

MeLleY: Well, why are they arresting the women? Why aren't they arresting the people who won't let them walk through?

том: I, uh....

Tom is interrupted by someone who starts talking to him. Melley walks away. She returns to Mazie, who is still standing near the seated women. They watch as the police come over to the group and roughly drag two women to the truck. The police are red faced and angry. Next they return and pick up an elderly woman who is dressed in a neat wraparound skirt and $a$ T-shirt. They grab her by the wrists and ankles and roughly lift her so that her skirt goes flying over her head as they carry her away. Melley 
watches in disbelief. After the next woman is carried away Melley sits down and takes her place in the circle. Mazie is obviously amazed. A sheriff's deputy comes over and starts to grab her wrists, but Melley stands $u p$ and faces him instead.

DEPUTY 2 (surprised when he recognizes her): What are you doing here? MELLEY: What are you doing here?

Deputy 2 looks away, walks her over to the police van, puts her in.

MAN IN CROWD (standing near Tom Kleman): That's awful funny, the wife of the bank president being put in the police truck like that. (Calling out to Tom) Hey, Tom, they just took your wife away!

YOUNG MAN (Runs up to Tom): Mr. Kleman, Mr. Kleman, they just put Mrs. Kleman in the paddy wagon!

том: Come on, this is no time for fooling around, this is serious.

YOUNG MAN (sincerely, with wide eyes): I'm not kidding!

\section{Scene 2}

Inside the police van. A sheriff's deputy armed with rifle, pistols, and extra ammunition gets in and closes the door, standing next to it. Inside, the truck is dark and steamy.

ARRESTED WOMAN I: I wonder where they're going to take us. How long are we going to be in here?

MELLEY: You're only going to go two blocks

ARRESTED WOMAN I: You know that? You mean you're from around here? MELLEY: Yeah.

Melley starts to stand up.

DEPUTY 3: Get back on that floor.

MELLEY: I only want to look out the window. My husband doesn't know I got arrested. I want to see if I can see him.

DEPUTY 3 (angry): Sit down!

Truck starts to move away. Women are silent and frightened until they arrive at the sheriff's department. The door opens and the arrested women are led into an outdoor recreation yard. One side is fenced and three sides are concrete walls. A broken basketball hoop hangs from one wall; two broken picnic tables stand in one corner. Little patches of grass pop up from the otherwise bare dirt. About forty arrested women are already in the yard as this last group of about fourteen arrested women comes in. 
ARRESTED WOMAN I (just getting out of the van): We're the last ones. SEVERAL ARRESTED WOMEN: We need to form a circle. Let's form a circle. Arrested women begin to gather in a circle. Several women stay outside the circle's edge. Melley and another woman sit on the picnic tables. Several others stand in the shade, crying. The arrested women begin to talk in turn, introducing themselves and expressing thoughts and ideas.

ARRESTED WOMAN 3: My name is Kerry, and, uh, I'll speak first. First, are there any doctors or lawyers here? (The arrested women look at each other but no one answers.) No? (One arrested woman puts her hand up tentatively.) Are you?

ARRESTED WOMAN 4: I'm just a legal assistant.

ARRESTED WOMAN 3: Okay, then, our first job is to get some lawyers in here.

ARRESTED WOMAN 5: I've got to go to the bathroom.

ARRESTED WOMAN 3: Yeah, we've got to set up some sort of facilities here. SEVERAL ARRESTED WOMEN: Yeah, we need it, we'd better soon (giggles). ARRESTED WOMAN 6: We need some water too.

Arrested women within the circle continue discussing the situation. Deputy 3 comes in while they are talking.

SEVERAL ARRESTED wOMEN: We need a bathroom. Yeah, and some water. Can you hurry up please.

Deputy 3 goes out and reenters with a matron a few minutes later.

MATRON: Okay, whoever wants to use the bathroom, I can only take you out one at a time. (Arrested women groan.) Line up!

A few arrested women get in line. The rest wait in the circle. The matron walks out with one woman. Other arrested women continue talking in the circle.

ARRESTED WOMAN 7: I usually don't give my name when I'm arrested. I go by Jane Doe and I'm going to do that this time too.

ARRESTED WOMAN 8: Look, they're going to come out and threaten us if we don't use our right names. They're going to threaten us with very long jail terms, but don't be afraid of that. They can't do that; that's just a threat. Don't let them scare you.

MELLEY: What's wrong with giving your name? I'm going to give my name because I want, you know, to get out of here.

ARRESTED WOMAN I: She's the lady that's local! 
ARRESTED WOMAN 9: Can you tell us where we are?

MELLEY: This is the sheriff's jail in Waterloo. This is the county seat of Seneca County so this is the county's jail. We're just a few blocks from the bridge; they didn't take us far. I live here in Waterloo, and I don't know what happened. It just looks like everybody was nuts, you know. I just can't believe this happened. But I can't believe anything else bad will happen to us, I hope. But I don't understand why we can't give our names, why you don't want to give your names.

ARRESTED WOMAN 9: I was just, some of us were just arrested for protesting nuclear subs in Groton, Connecticut, and if they find out I was arrested before, they'd treat me worse now.

ARRESTED WOMAN IO: Yeah, if they find out that you are a repeater they get more harsh. Some of us have already gone over the fence at the depot. I'm going as Jane Doe too. (Other women nod in agreement.)

Deputy 3 comes in. He angrily reads an announcement that the women are going to be arrested and that they must give their true names or face three to five years in jail.

ARRESTED WOMAN 3: We're getting hungry. Can we get some food, some sandwiches or anything?

DEPUTY 3 (red and angry): Who the hell do you think you are. You don't deserve nothing and we don't have to feed you until dinnertime. You disrupted this town, this jail, completely. We'll do what we can but we can't handle a bunch of people like you. We'll be coming back soon to process you, so line up.

Deputy 3 leaves. Arrested women continue to talk in circle. Deputy 3 returns with deputy 4.

DEPUTY 3: Okay, who's first? (Melley raises her hand, but he doesn't see it; he angrily grabs an old woman in front of him and shoves ber toward deputy 4.) You're first. Get going.

MELLEY: I'll volunteer.

DEPUTY 3: Okay, you're second. Come with me (grabs her arm and leads her out).

Deputy 3 leads Melley to a room in the jail, where she sees another woman sitting on a chair, sobbing. Deputy 5 tries to measure her height but fumbles with the measuring device. Melley is taken over to have her picture taken. A sign with her name and number is put around her neck. She is told to hold it in front of her chest. Deputy 6 complains she is too short, and he can't see sign. She puts it higher, but it is tilted. Finally, the 
picture is taken. Melley is then directed to a seat across the table from matron 2. The other woman is seated at a similar table next to her, sobbing. Two deputies are standing behind matron 2, who is nervous.

MATRON 2: What's your name.

MELLEY: Mrs. Melley Kleman.

MATRON 2: Date of birth?

MELLEY: November 6, 1927.

MATRON 2: What's your address? (She writes the answer.)

MELLEY: Waterloo.

MATRON 2: What race are you?

DEPUTY 7 (leans over to her): We're putting them all down as Caucasian. It doesn't matter what they say.

MATRON 2: What color are your eyes?

MELLEY: Blue.

MATRON 2: What color is your hair?

MELLEY: Gray.

DEPUTY 7 (interrupts before she can write it down): Gray is not a legal color.

Matron and Melley look at each other. No one speaks for a few seconds. MELLEY: Well, you know, I used to be blond.

MATRON 2 (looking up at deputy): Well, what do you want me to write? DEPUTY 5 (leaning over and looking at Melley's hair): I still see some blond there. Put blond-gray down. Yeah, put blond-gray.

Matron I writes on form. Next to Melley, the other woman is sobbing and refuses to answer any questions.

DEPUTY 8 (screaming at other woman): You're going to sit here till you tell us your name, lady. Don't think you're gonna pull this stuff on us. I don't care what you do when you're arrested at the depot-we aren't gonna take that sort of stuff. You can pull that off in the city, but you can't pull it off here. We're going to fill out this form if it takes five days. What is your name? When were you born? What is the color of your hair.

The woman continues to sob.

DEPUTY 3 (to Melley): You're done. Take her back to the bullpen.

Melley stands up, but doesn't know which way to go. Matron 4 comes up behind her, pushes Melley's back.

MATRON 4: Walk along, you. 
Melley and Matron 4 walk back to the area where the arrested women are gathered. They all rush over to greet Melley since she is the first to return. She explains what happened. Arrested women come over one by one to thank her.

ARRESTED WOMAN IO: Thank you for doing this with us. It means a lot since you're from around here.

ARRESTED WOMAN I I: Yeah, really, you're really brave.

MELLEY: I don't think of what I did as brave.

ARRESTED WOMAN I 2: It's so wonderful. Thanks.

Deputy 3 brings in a woman lawyer, who addresses the group.

LAWYER: I'm a lawyer from the encampment. Things are a little crazy and confusing outside. The townspeople have gathered outside the jail, and a lot of the women from the encampment are there too. The cops have separated the townspeople from us, but it is still very threatening. I don't think there will be another confrontation, but I don't know. The women are setting up a vigil to wait for you. We're working to get you out. First thing, don't let them frighten you. You don't have to give your name if you don't want. They can't force you. This whole thing is going to be really slow because the police are not prepared for this. Also, they know they are in the wrong and don't know what to do.

Deputy 3, who is standing there listening, grabs the lawyer's arm and starts to pull her back out the door.

DEPUTY 3: That's long enough. You've had all the time you can have with them.

He pulls the lawyer out the door. Deputy 4 comes back in with sobbing other woman. Arrested women gather around her as she cries. Deputy 4 stays near the door.

ARRESTED WOMEN: What happened? What did they do to you? OTHER WOMAN (sobbing): Just give me a minute.

The other woman walks over to the fence, puts her hands on it, and bangs her head lightly against it as she cries. Deputy 4 comes running over, grabs her arm, and spins her around.

DEPUTY 4: Look, lady, I don't know what kind of pigpen you come from, but we keep a clean, neat jail here, and you ain't going to rub hair grease all over our fence. You keep you hands off that fence. We ain't going to repaint it after you. 
Several arrested women come over to the other woman, put their arms around her, and lead her away as she tells them about her interrogation. Several other arrested women come up to Melley.

ARRESTED WOMAN I 3: We don't know if we will ever see you again, but can I thank you now?

MELLEY: Oh, you'll see me again.

ARRESTED WOMAN I 4: Oh, I don't think so. Thanks. You'll be going soon. DEPUTY 3(shouting): Melley Kleman? (Melley raises her hand.) Come with me.

Melley walks out with deputy 3. Arrested women say goodbye. 